\title{
Prototype Monitoring Kondisi Pengiriman Telur Berbasis Arduino
}

\author{
Ferry Sudarto $^{1}$, Hendra kusumah ${ }^{2}$, Nursohit $^{3}$ \\ Jurusan Sistem Komputer,Universitas Raharja, Tangerang \\ e-mail: *ferry.sudarto@ raharja.info, ${ }^{2}$ hendra.kusumah@raharja.info, \\ 3 nursohit@ raharja.info
}

\begin{abstract}
ABSTRAK
Distribusi merupakan kegiatan penyaluran barang secara langsung maupun tidak langsung. Dalam perusahan telur, seperti CV. Pirius Jaya Abadi, proses distribusi memiliki peran penting dikarenakan tahapan distribusi yang akan menyalurkan hasil pengolahan telur ke konsumen. Ketika telur berada dalam box mobil distribusi telur akan menghadapi beberapa kondisi yaitu guncangan yang mengakibatkan telur bisa pecah, lamanya paparan suhu yang mengakibatkan pencemaran bakteri salmonella dalam telur. Pada penelitian ini dituju terhadap proses pengiriman ketika telur berada pada mobil pengiriman. Untuk mengetahui kondisi pengiriman telur, prototype ini akan melakukan monitoring suhu, getaran di setiap peti nya dan jika suhu mencapai lebih besar $25^{\circ}$ celcius maka kipas akan menyala. Dalam hasil pengujian mendapatkan nilai rata-rata $1.12 \mathrm{~Hz}$ dalam keadaan normal dan mendapatkan nilai rata-rata $0.37 \mathrm{~Hz}$ dalam keadan guncangan yang dapat berpotensi memecahkan telur sehingga mengirimkan notifikasi sms ke supir. Konsumen dapat menerima sms apabila pesanan telah sampai. Posisi pengiriman dapat di monitoring setiap data monitoring dapat dilihat dalam aplikasi berbasis web.
\end{abstract}

Kata Kunci: Prototype Pengiriman Kondisi Telur, Arduino MKR GSM 1400, Adxl335, DHT21, GPS Neo 6-m

\begin{abstract}
Distribution is a distribution activity directly or indirectly. In egg companies, like a CV. Pirius Jaya Abadi, the distribution process has an important role due to the distribution stages that will distribute the results of egg processing to consumers. When eggs are in a distribution car box The egg will face several conditions namely vibration the egg can break duration of exposure to temperature issued result pollution of salmonella bacteria in eggs. This study aimed at the delivery process when the eggs are in the delivery car. To determine the condition of egg delivery, this prototype will do temperature monitoring, vibration in each crate and if the temperature reaches $25^{\circ}$ Celsius greater than the fan will turn on. In the test results, get an average value of $1.12 \mathrm{~Hz}$ under normal conditions and get an average value of $0.37 \mathrm{~Hz}$ in a shocking state that can solve the problem by sending an sms notification to the driver. Consumers can receive sms when the order has arrived. Delivery position can be monitored, every monitoring data can be seen in a web-based application.
\end{abstract}

Keywords: Egg Condition Delivery Prototype, Arduino MKR GSM 1400, Adxl335, DHT21, GPS Neo 6-m 


\section{PENDAHULUAN}

Distribusi merupakan kegiatan penyaluran barang secara langsung maupun tidak langsung, konsumen dapat menerima barang yang di pesan melalui proses pengiriman dari pihak produsen tidak melalui pihak ketiga, atau konsumen dapat menerima barang yang di pesan melalui proses pengiriman dari pihak ketiga yang dimana produsen memberikan barang serta alamat yang akan dikirim ke jasa pengiriman setelah itu barang akan dikirim ke konsumen.

Namun pada penelitian ini dituju terhadap proses pengiriman ketika telur berada pada mobil pengiriman. Untuk mengetahui kondisi pengiriman telur, prototype ini akan melakukan monitoring suhu, getaran di setiap peti nya dan jika suhu mencapai lebih besar 25 celcius maka kipas akan menyala. Ketika proses pengiriman mengalami getaran yang berpotensi mengakibatkan telur pecah maka akan mengirimkan notifikasi sms ke supir. Posisi pengiriman dapat di monitoring setiap data monitoring dapat dilihat dalam aplikasi berbasis web.

\section{METODE PENELITIAN}

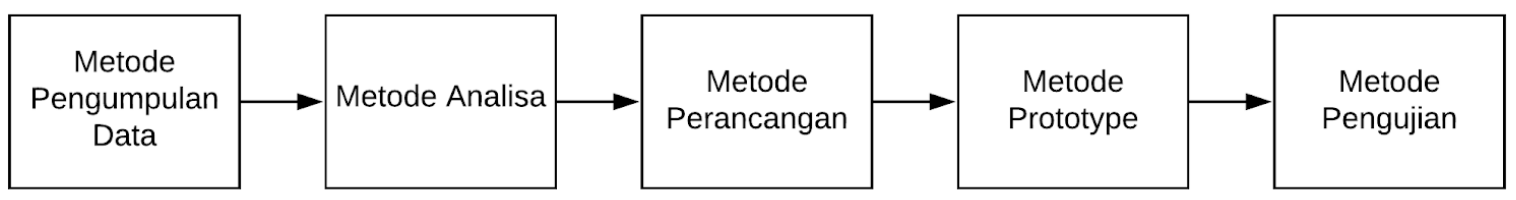

Gambar 1. Metode Penelitian

\section{Keterangan :}

1. Metode Pengumpulan Data

a. Observasi (Observation)

Dalam metode ini peneliti melakukan observasi ke CV Pirius Jaya Abadi, selama 6 bulan.

b. Wawancara (Interview)

untuk mendapatkan data dan keterangan-keterangan yang diinginkan dengan cara melakukan tanya jawab kepada stakeholder, pada CV Pirius Jaya Abadi membutuhkan alat yang dapat memonitoring kondisi pengiriman telur.

c. Studi Pustaka

peneliti juga melakukan studi pustaka, dengan cara pengumpulan data dari buku, berbagai jurnal, literature review baik dalam maupun luar negri.

2. Metode Analisa 
Pada metode ini penulis menganalisa sistem yang sudah ada dengan beberapa point pertibangan, seperti bagaimana cara kerja sistem, apa saja komponen yang membangun sistem tersebut dan juga kekurangan dari sistem tersebut, dan metode analisis yang digunakan adalah metode waterfall.

3. Metode Perancangan

Dalam laporan ini, perancangan yang digunakan adalah metode perancangan melalui tahap pembuatan flowchart sistem dan desain hardware menggunakan diagram blok loop tertutup dan loop terbuka. Metode ini dimaksudkan bagaimana sistem itu dirancang dan komponen apa saja yang dibutuhkan.

\section{Metode Prototype}

Metode yang dipakai adalah metode Throw-away Prototyping, karena dengan Throw-away Prototyping ini dapat mengurangi resiko kebutuhan yang tidak dapat dipenuhi.

5. Metode Pengujian

Metode testing ini digunakan untuk menganalisa suatu identitas sistem untuk mendeteksi, mengevaluasi kondisi dan fitur-fitur yang diinginkan dan mengetahui kualitas dari suatu sistem yang dilakukan untuk mendeteksi kesalahan yang terjadi saat sistem diterapkan. Penulis menggunakan metode Black Box karena untuk menemukan kesalahan dalam beberapa kategori.

Berikut ini tabel daftar literature review yang digunakan dalam penelitian ini:

\begin{tabular}{|c|c|c|c|c|c|c|}
\hline $\begin{array}{l}\mathrm{N} \\
\mathrm{O}\end{array}$ & $\begin{array}{l}\text { Tahun } \\
\text { /Penulis }\end{array}$ & $\begin{array}{l}\text { Tujuan } \\
\text { Penelitian }\end{array}$ & Permasalahan & $\begin{array}{l}\text { Methodology } \\
\text { Yang } \\
\text { Digunakan }\end{array}$ & Findings & $\begin{array}{l}\text { Kesimpula } \\
\mathrm{n}\end{array}$ \\
\hline 1. & $\begin{array}{l}\text { Pangestu, } \\
\text { A., } \\
\text { Sumardi, S. } \\
\text { dan } \\
\text { Sudjadi, S., } \\
2014 .\end{array}$ & $\begin{array}{l}\text { Dengan } \\
\text { semakin } \\
\text { berkembangny } \\
\text { a teknologi, } \\
\text { perangkat GPS } \\
\text { dapat kita } \\
\text { gunakan } \\
\text { sebagai alat } \\
\text { untuk melacak } \\
\text { kendaraan kita } \\
\text { dari tindak } \\
\text { pidana } \\
\text { pencurian. }\end{array}$ & $\begin{array}{l}\text { sulitnya tim } \\
\text { penyelidik } \\
\text { untuk mencari } \\
\text { lokasi } \\
\text { kendaraan } \\
\text { yang dicuri } \\
\text { tersebut } \\
\text { berada. Salah } \\
\text { satu solusi } \\
\text { yang bisa } \\
\text { dilakukan } \\
\text { adalah dengan } \\
\text { memasang } \\
\text { pelacak pada } \\
\text { sepeda motor } \\
\text { kita. }\end{array}$ & $\begin{array}{ll}\text { 1. } & \begin{array}{l}\text { Global } \\
\text { Positioni } \\
\text { ng }\end{array} \\
& \text { System } \\
& \text { (GPS) } \\
\text { 2. } & \begin{array}{l}\text { Mikroko } \\
\text { ntroler }\end{array} \\
& \text { AVR } \\
& \text { ATMEG } \\
& \text { A644PA } \\
\text { 3. } & \text { General } \\
& \text { Packet } \\
& \text { Radio } \\
& \text { Service } \\
\text { (GPRS) }\end{array}$ & $\begin{array}{l}\text { Atmega644PA } \\
\text { merupakan } \\
\text { sebuah } \\
\text { mikrokontroler } \\
\text { low power } \\
\text { CMOS } 8 \text { bit } \\
\text { berdasarkan } \\
\text { arsitektur AVR } \\
\text { RISC. }\end{array}$ & $\begin{array}{l}\text { Berdasarka } \\
\text { n beberapa } \\
\text { pengujian } \\
\text { dan } \\
\text { analisis } \\
\text { yang } \\
\text { dilakukan } \\
\text { pada alat } \\
\text { pelacak } \\
\text { dan } \\
\text { pengaman } \\
\text { sepeda } \\
\text { motor, } \\
\text { modul } \\
\text { GPS Ublox } \\
\text { Neo } 6 \mathrm{M} \\
\text { yang } \\
\text { digunakan } \\
\text { sebagai } \\
\text { sensor } \\
\text { posisi, data }\end{array}$ \\
\hline
\end{tabular}




\begin{tabular}{|c|c|c|c|c|c|c|}
\hline $\begin{array}{l}\mathrm{N} \\
\mathrm{O}\end{array}$ & $\begin{array}{l}\text { Tahun } \\
\text { /Penulis }\end{array}$ & $\begin{array}{l}\text { Tujuan } \\
\text { Penelitian }\end{array}$ & Permasalahan & $\begin{array}{l}\text { Methodology } \\
\text { Yang } \\
\text { Digunakan }\end{array}$ & Findings & $\begin{array}{l}\text { Kesimpula } \\
\mathrm{n}\end{array}$ \\
\hline & & & & & & $\begin{array}{l}\text { posisi } \\
\text { lintang dan } \\
\text { bujur yang } \\
\text { didapat } \\
\text { tidak } \\
\text { meleset } \\
\text { terlalu jauh } \\
\text { dengan } \\
\text { data } \\
\text { koordinat } \\
\text { posisi yang } \\
\text { digunakan } \\
\text { sebagai } \\
\text { titik acuan, } \\
\text { dengan } \\
\text { selisih } \\
\text { sekitar } \\
0,23 \text { "- } \\
0,25 \text { " } \\
\text { untuk } \\
\text { koordinat } \\
\text { lintang dan } \\
0,02 \text { "- } \\
0,05 \text { " } \\
\text { untuk } \\
\text { koordinat } \\
\text { bujur }\end{array}$ \\
\hline 2. & $\begin{array}{l}\text { Santoso, H. } \\
\text { dan } \\
\text { Suryaprada } \\
\text { na, I., } 2018 .\end{array}$ & $\begin{array}{l}\text { untuk } \\
\text { merancang } \\
\text { sensor } \\
\text { monitoring } \\
\text { suhu laptop } \\
\text { yang } \\
\text { memanfaatkan } \\
\text { IC LM35 dan } \\
\text { ADC 0804 } \\
\text { yang didesain } \\
\text { sedemikian } \\
\text { rupa sehingga } \\
\text { dapat } \\
\text { mendeteksi } \\
\text { suhu dari } \\
\text { laptop yang } \\
\text { digunakan } \\
\text { sehingga dapat } \\
\text { dijadikan } \\
\text { sebagai } \\
\text { monitoring dan } \\
\text { salah satu } \\
\text { langkah } \\
\text { perawatan } \\
\text { laptop / } \\
\text { computer }\end{array}$ & $\begin{array}{l}\text { Panas dari } \\
\text { CPU yang } \\
\text { mempengaruh } \\
\text { i panas } \\
\text { keseluruhan } \\
\text { komponen } \\
\text { laptop/PC } \\
\text { lainnya } \\
\text { sehingga akan } \\
\text { mempengaruh } \\
\text { i kinerja } \\
\text { laptop/PC. }\end{array}$ & 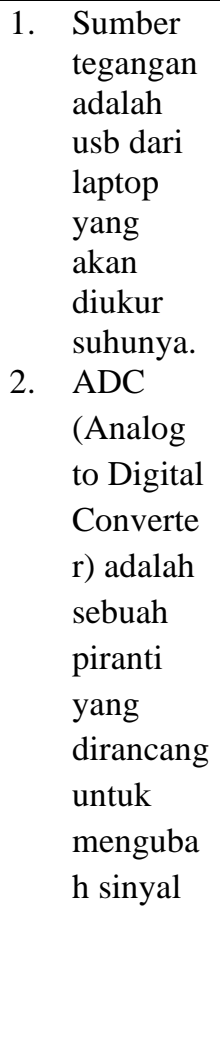 & $\begin{array}{l}\text { Aman: suhu } \\
\text { normal } \\
\text { komputer aktif } \\
\text { secara } \\
\text { keseluruhan, } \\
\text { yaitu 400C } \\
\text { hingga 600C. } \\
\text { Maka dari itu } \\
\text { menurut } \\
\text { penulis, suhu } \\
\text { aman komputer } \\
\text { adalah dibawah } \\
\text { 50 derajat C. }\end{array}$ & $\begin{array}{l}\text { Sensor dan } \\
\text { monitoring } \\
\text { komputer } \\
\text { ini adalah } \\
\text { sebagai } \\
\text { salah satu } \\
\text { cara } \\
\text { perawatan } \\
\text { dengan } \\
\text { mengetahu } \\
\text { i tingkat } \\
\text { suhu pada } \\
\text { saat } \\
\text { penggunaa } \\
\text { n. }\end{array}$ \\
\hline 3. & Sembiring, & Untuk & Kasus & 1. Persiapan & 1. Menghasilk & Alat \\
\hline
\end{tabular}




\begin{tabular}{|c|c|c|c|c|c|c|}
\hline $\begin{array}{l}\mathrm{N} \\
\mathrm{O}\end{array}$ & $\begin{array}{l}\text { Tahun } \\
\text { /Penulis }\end{array}$ & $\begin{array}{l}\text { Tujuan } \\
\text { Penelitian }\end{array}$ & Permasalahan & $\begin{array}{l}\text { Methodology } \\
\text { Yang } \\
\text { Digunakan }\end{array}$ & Findings & $\begin{array}{l}\text { Kesimpula } \\
\mathrm{n}\end{array}$ \\
\hline & $\begin{array}{l}\text { Z. and } \\
\text { Muliono, } \\
\text { R., } 2019\end{array}$ & $\begin{array}{l}\text { menghasilkan } \\
\text { satu rancangan } \\
\text { alat pelacak } \\
\text { lokasi anak } \\
\text { yang dapat } \\
\text { mengantisipasi } \\
\text { penculikan } \\
\text { anak }\end{array}$ & $\begin{array}{l}\text { penculikan } \\
\text { anak selalu } \\
\text { meningkat } \\
\text { dari tahun ke } \\
\text { tahun } \\
\text { berdasarkan } \\
\text { sumber dari } \\
\text { Komisi } \\
\text { Perlindungan } \\
\text { Anak } \\
\text { Indonesia } \\
\text { (KPAI). }\end{array}$ & $\begin{array}{l}\text { perangkat } \\
\text { keras dan } \\
\text { lunak } \\
\text { yang } \\
\text { dibutuhk } \\
\text { an. } \\
\text { 2. } \\
\text { Perancan } \\
\text { gan } \\
\text { rangkaian } \\
\text { perangkat } \\
\text { keras. } \\
\text { 3. } \\
\text { Pembuata } \\
\text { n kode } \\
\text { program } \\
\text { sesuai } \\
\text { rancanga } \\
\text { n } \\
\text { rangkaian } \\
\text { dan } \\
\text { pengujian } \\
\text { perangkat } \\
\text { keras dan } \\
\text { lunak }\end{array}$ & $\begin{array}{ll}\text { an } \\
\text { informasi } \\
\text { lokasi yang } \\
\text { akurat, } \\
\text { 2. Aplikasi } \\
\text { yang sangat } \\
\text { mudah } \\
\text { digunakan } \\
\text { serta } \\
\text { komponen } \\
\text { perangkat } \\
\text { keras dan } \\
\text { perangkat } \\
\text { lunak dapat } \\
\text { berjalan } \\
\text { dengan } \\
\text { baik. }\end{array}$ & $\begin{array}{l}\text { pelacak } \\
\text { lokasi } \\
\text { dapat } \\
\text { digunakan } \\
\text { dengan } \\
\text { mudah } \\
\text { baik bagi } \\
\text { orang tua } \\
\text { maupun } \\
\text { anak } \\
\text { mereka } \\
\text { sehingga } \\
\text { dapat } \\
\text { mengantisi } \\
\text { pasi } \\
\text { tindakan } \\
\text { penculikan } \\
\text { anak. }\end{array}$ \\
\hline 4. & $\begin{array}{l}\text { Sulthoni, A. } \\
\text { and } \\
\text { Suprianto, } \\
\text { B., 2018. }\end{array}$ & $\begin{array}{l}\text { untuk } \\
\text { menghasilkan } \\
\text { sebuah alat } \\
\text { pendeteksi } \\
\text { sistem vibrasi } \\
\text { pada motor } \\
\text { sebagai } \\
\text { indikator } \\
\text { pengaman } \\
\text { terhadap } \\
\text { perubahan } \\
\text { beban } \\
\text { menggunakan } \\
\text { sensor } \\
\text { Accelerometer } \\
\text { GY-521 MPU } \\
6050 \text { berbasis } \\
\text { Arduino Uno. }\end{array}$ & $\begin{array}{l}\text { Gangguan ini } \\
\text { jika tidak } \\
\text { segera } \\
\text { terdeteksi } \\
\text { akan } \\
\text { menyebabkan } \\
\text { kerusakan } \\
\text { yang dapat } \\
\text { menghambat } \\
\text { proses } \\
\text { produksi }\end{array}$ & $\begin{array}{l}\text { Secara umum } \\
\text { implementasi } \\
\text { prototipe } \\
\text { sistem } \\
\text { pendeteksi } \\
\text { vibrasi pada } \\
\text { motor } \\
\text { terhadap } \\
\text { perubahan } \\
\text { beban ini } \\
\text { dimulai } \\
\text { dengan switch } \\
\text { on sumber } \\
\text { listrik PLN } \\
\text { hardware } \\
\text { aktif, motor } \\
\text { induksi } 1 \text { fasa } \\
\text { bekerja akan } \\
\text { mensimulasik } \\
\text { an vibrasi } \\
\text { atau getaran } \\
\text { yang terjadi } \\
\text { pada kondisi } \\
\text { pada saat } \\
\text { motor } \\
\text { berbeban } \\
\text { maupun tidak } \\
\text { berbeban. }\end{array}$ & $\begin{array}{l}\text { sensor vibrasi } \\
\text { Accelerometer } \\
\text { GY-521 MPU } \\
6050 \text { memiliki } \\
\text { sensitivitas yang } \\
\text { cukup tinggi } \\
\text { dan bekerja } \\
\text { dengan baik. }\end{array}$ & $\begin{array}{l}\text { Pada } \\
\text { pengujian } \\
\text { pengukura } \\
\text { n vibrasi } \\
\text { dengan } \\
\text { mengguna } \\
\text { kan beban } \\
<3 \mathrm{Kg} \\
\text { nilai } \\
\text { vibrasi } \\
\text { yang } \\
\text { dihasilkan } \\
\text { oleh motor } \\
\text { sebesar } \\
0.48 \mathrm{~mm} / \mathrm{s} \text {, } \\
1.74 \mathrm{~mm} / \mathrm{s} \text {, } \\
1.78 \mathrm{~mm} / \mathrm{s} \text {, } \\
2.01 \mathrm{~mm} / \mathrm{s} \text {, } \\
2.19 \mathrm{~mm} / \mathrm{s} \text {, } \\
\text { dan } 2.35 \\
\mathrm{~mm} / \mathrm{s} \mathrm{serta} \\
\text { masih } \\
\text { dalam } \\
\text { batas yang } \\
\text { diizinkan }\end{array}$ \\
\hline 5. & $\begin{array}{l}\text { Zarkasi, } \\
\text { M.I., Endri, } \\
\text { J. dan }\end{array}$ & $\begin{array}{l}\text { Alat ini dibuat } \\
\text { untuk mengatur } \\
\text { suhu dan }\end{array}$ & $\begin{array}{l}\text { Salah satu } \\
\text { gangguan } \\
\text { yang }\end{array}$ & $\begin{array}{ll}\text { 1. } & \text { Studi } \\
& \text { pustaka } \\
\text { 2. } & \text { Konsulta } \\
\end{array}$ & $\begin{array}{l}\text { Alat ini dibuat } \\
\text { menggunakan } \\
\text { arduino uno }\end{array}$ & $\begin{array}{l}\text { Aplikasi di } \\
\text { android } \\
\text { juga tidak }\end{array}$ \\
\hline
\end{tabular}




\begin{tabular}{|c|c|c|c|c|c|c|}
\hline $\begin{array}{c}\mathrm{N} \\
\mathrm{O}\end{array}$ & $\begin{array}{l}\text { Tahun } \\
\text { /Penulis }\end{array}$ & $\begin{array}{l}\text { Tujuan } \\
\text { Penelitian }\end{array}$ & Permasalahan & $\begin{array}{l}\text { Methodology } \\
\text { Yang } \\
\text { Digunakan }\end{array}$ & Findings & $\begin{array}{l}\text { Kesimpula } \\
\mathrm{n}\end{array}$ \\
\hline & $\begin{array}{l}\text { Sarjana, S., } \\
2019 .\end{array}$ & $\begin{array}{l}\text { kelembaban } \\
\text { ruang server } \\
\text { yang melebihi } \\
\text { batas wajar }\end{array}$ & $\begin{array}{l}\text { menyebabkan } \\
\text { server rusak } \\
\text { adalah suhu } \\
\text { yang terlalu } \\
\text { panas maka } \\
\text { dari itu alat ini } \\
\text { dibuat agar } \\
\text { dapat } \\
\text { mencegah } \\
\text { permasalahan } \\
\text { tersebut. }\end{array}$ & $\begin{array}{ll}\text { si dan } \\
\text { diskusi } \\
\text { 3. } & \text { Rancang } \\
\text { Bangun } \\
\text { Alat } \\
\text { Setelah } \\
\text { mengum } \\
\text { pulkan } \\
\text { referensi } \\
\text { 4. } & \text { Pengujia } \\
\text { n Alat } \\
\text { Setelah } \\
\text { melalui } \\
\text { proses } \\
\text { pengump } \\
\text { ulan data }\end{array}$ & $\begin{array}{l}\text { sebagai } \\
\text { mikrokontroler, } \\
\text { DHT11 sebagai } \\
\text { sensor suhu dan } \\
\text { kelembaban, } \\
\text { Ethernet shield } \\
\text { sebagai } \\
\text { penghubung ke } \\
\text { internet. }\end{array}$ & $\begin{array}{l}\text { terdapat } \\
\text { masalah } \\
\text { saat } \\
\text { dilakukan } \\
\text { pengujian } \\
\text { hanya saja } \\
\text { jika sinyal } \\
\text { pada } \\
\text { operator } \\
\text { buruk } \\
\text { maka nilai } \\
\text { yang } \\
\text { dikirimkan } \\
\text { dari sensor } \\
\text { sedikit } \\
\text { terlambat } \\
\text { sampai. }\end{array}$ \\
\hline
\end{tabular}

\section{HASIL DAN PEMBAHASAN}

\subsection{Analisis Prototype}

Dalam prototype ini menggunakan analisis Waterfall dan prototype jenis Throw-away Prototyping, maka akan dibuat tabel perbandingan berdasarkan hasil perbandingan yang telah dilakukan.

Tabel 3.1 Perbandingan Waterfall dan Prototype Jenis Throw-away Prototyping

\begin{tabular}{|l|l|l|l|}
\hline No & $\begin{array}{l}\text { Tahap Pengembangan } \\
\text { Perangkat Lunak Dan } \\
\text { Perangkat Lunak }\end{array}$ & Waterfall & \multicolumn{1}{c|}{ Prototyping } \\
\hline $\mathbf{1}$ & $\begin{array}{l}\text { Perancangan Sistem } \\
\text { Systems Planning })\end{array}$ & $\begin{array}{l}\text { Berawal dari pengajuan } \\
\text { proposal ke perusahan dan } \\
\text { judul ke kepala jurusan. }\end{array}$ & $\begin{array}{l}\text { Berawal dari pengajuan } \\
\text { proposal ke perusahaan dan } \\
\text { judul ke kepala jurusan }\end{array}$ \\
\hline
\end{tabular}




\begin{tabular}{|c|c|c|c|}
\hline No & $\begin{array}{l}\text { Tahap Pengembangan } \\
\text { Perangkat Lunak Dan } \\
\text { Perangkat Lunak }\end{array}$ & Waterfall & Prototyping \\
\hline 2 & $\begin{array}{l}\text { Analisis Sistem (Systems } \\
\text { Analysis) }\end{array}$ & 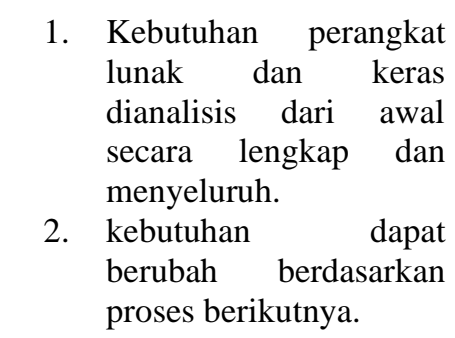 & $\begin{array}{l}\text { Kebutuhan perangkat lunak } \\
\text { dan keras dapat ditambah } \\
\text { sesuai dengan hasil } \\
\text { bimbingan dengan dosen } \\
\text { pembimbing dan kebutuhan } \\
\text { stakeholder. }\end{array}$ \\
\hline 3 & $\begin{array}{l}\text { Perancangan } \quad \text { Sistem } \\
\text { Desain (Systems Design) }\end{array}$ & $\begin{array}{l}\text { Dalam perancangan sistem } \\
\text { desain } \\
\text { flowchart. }\end{array}$ & $\begin{array}{l}\text { Dalam perancangan sistem } \\
\text { menggunakan diagram blok }\end{array}$ \\
\hline 4 & Implementasi & $\begin{array}{l}\text { Implementasi menggunakan } \\
\text { bahasa arduino dan PHP. }\end{array}$ & $\begin{array}{l}\text { Implementasi harus } \\
\text { mendapat persetujuan dari } \\
\text { stakeholder }\end{array}$ \\
\hline 5 & Testing & $\begin{array}{l}\text { 1. Menggabungkan bahasa } \\
\text { arduino per modul. } \\
\text { 2. Mengirimkan data dari } \\
\text { bahasa arduino ke } \\
\text { bahasa PHP }\end{array}$ & $\begin{array}{lll}\text { Melihat hasil dari } & \text { setiap } \\
\text { rangkaian yang } & \text { sudah } \\
\text { terpasang } & & \end{array}$ \\
\hline 6 & $\begin{array}{l}\text { Pemeliharaan } \\
\text { Sistem } \\
\text { (Systems } \\
\text { Maintenance) }\end{array}$ & $\begin{array}{l}\text { Dilakukan jika } \\
\text { kesepakatan }\end{array}$ & $\begin{array}{l}\text { Dilakukan jika } \\
\text { kesepakatan }\end{array}$ \\
\hline
\end{tabular}

\subsection{Flowchart Sistem Yang Diusulkan}

Ketika proses loading sudah selesai, Driver menekan Tactile Switch untuk memberikan status pengiriman bahwa pengiriman sedang berjalan, kemudian prototype mendeteksi apakah suhu lebih besar dari 26 derajat celcius, jika iya maka kipas DC akan menyala, apakah guncangan lebih besar dari 5.00 z-axis maka driver akan menerima sms, apakah pesanan sudah sampai, jika iya maka driver menekan tactile switch guna memberikan SMS ke konsumen bahwa pesanan sudah sampai, serta memberikan status bahwa sedang kembali di kantor. 
Admin dapat memonitoring setiap kondisi pengiriman melalui halaman web secara online, data yang dapat dilihat, suhu, z-axis, posisi pengiriman.Berikut

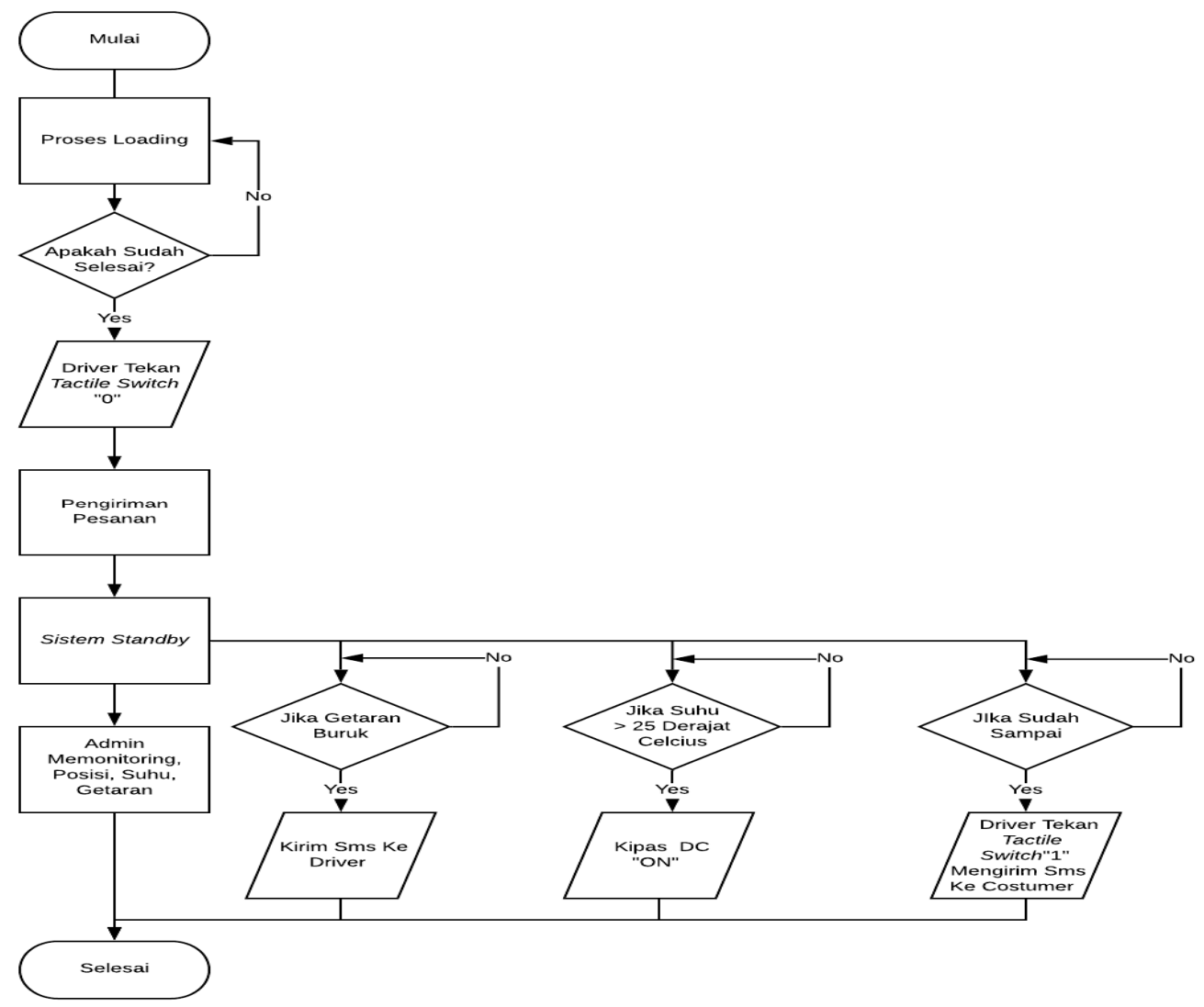

flowchart yang diusulkan pada CV. Perius Jaya Abadi sebagai berikut:

\subsection{Rancangan Prototype}

\section{Gambar 3.1 Gambar Flowchart Yang Diusulkan}




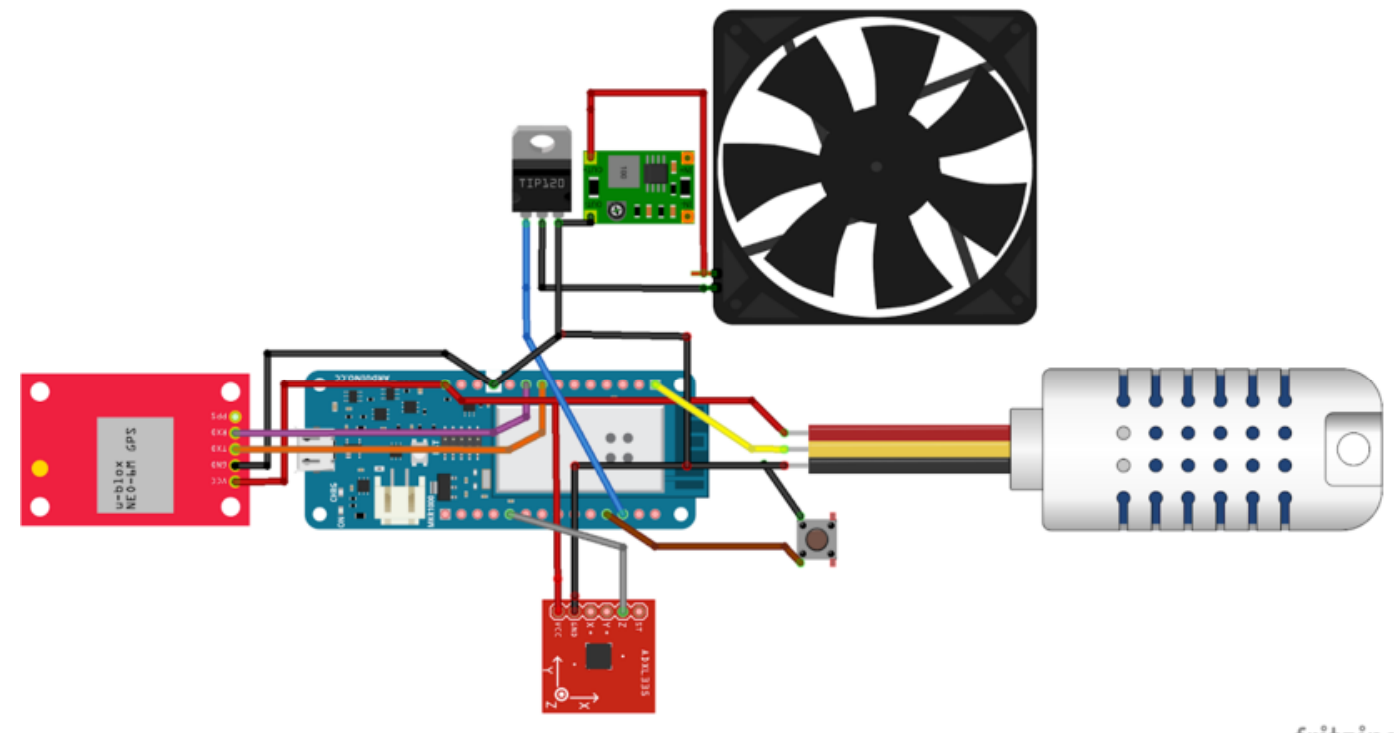

Gambar 3.2 Gambar Flowchart Yang Diusulkan

\section{3. $\quad$ Testing}

Dalam pengujian menggunakan metode black box, berikut pengujiannya:

Test 1

1. Monitoring guncangan telur didalam miniatur yang dibuat

2. Monitoring suhu telur didalam miniatur yang dibuat

Tabel Test 1

\begin{tabular}{|c|c|c|c|c|c|}
\hline No & $\begin{array}{c}\text { Skenario } \\
\text { Pengujian }\end{array}$ & Tes Case & $\begin{array}{l}\text { Hasil Yang } \\
\text { Diharapkan }\end{array}$ & Pengujian & Kesimpulan \\
\hline 1 & $\begin{array}{l}\text { Memasuk } \\
10 \text { Butir Di } \\
\text { Dalam } \\
\text { Miniatur }\end{array}$ & 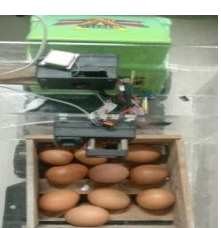 & $\begin{array}{l}\text { Dapat } \\
\text { Memonitorin } \\
\text { g Data Suhu } \\
\text { Di Dalam } \\
\text { Miniatur }\end{array}$ & {$[-\bar{\equiv}$} & Valid \\
\hline 2 & $\begin{array}{l}\text { Memasuk } \\
10 \text { Butir Di } \\
\text { Dalam } \\
\text { Miniatur }\end{array}$ & 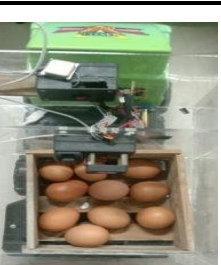 & $\begin{array}{l}\text { Dapat } \\
\text { Memonitorin } \\
\text { g Data } \\
\text { Guncangan } \\
\text { Di Dalam } \\
\text { Miniatur }\end{array}$ & {$\left[\begin{array}{c} \\
\vdots \\
\equiv \\
\\
\equiv \\
\end{array}\right.$} & Valid \\
\hline
\end{tabular}




\section{Test 2}

1. Mencari index z-axis yang dapat memecahkan telur

\section{Tabel Test 4}

\begin{tabular}{|l|l|l|c|c|c|}
\hline No & $\begin{array}{l}\text { Skenario } \\
\text { Pengujian }\end{array}$ & Tes Case & $\begin{array}{c}\text { Hasil } \\
\text { Yang } \\
\text { Diharapk } \\
\text { an }\end{array}$ & Pengujian & $\begin{array}{l}\text { Kesimpul } \\
\text { an }\end{array}$ \\
\hline $\mathbf{1}$ & $\begin{array}{l}\text { Mengconver } \\
\text { t nilai } \\
\text { analog } \\
\text { menjadi } \\
\text { digital } \\
\text { dibagi } \\
\text { dengan 1024 } \\
\text { hasilnya } \\
\text { dikurang } \\
\text { dengan hasil } \\
\text { pengurangan } \\
\text { nilai bias, } \\
\text { setelah itu } \\
\text { dibagi } \\
\text { dengan nilai } \\
\text { sensitivias. }\end{array}$ & $\begin{array}{c}\text { Dapat } \\
\text { memberik } \\
\text { an nilai } \\
\text { yang } \\
\text { diinginkan }\end{array}$ & & Valid \\
& & & & & \\
\hline
\end{tabular}

Tabel Penggunaan Sensor ADXL335

\begin{tabular}{|l|l|l|l|l|}
\hline $\begin{array}{l}\text { Tegangan } \\
\text { Yang } \\
\text { Diberikan }\end{array}$ & $\begin{array}{l}\text { Penggunaan } \\
\text { Bit Pada } \\
\text { Arduino } \\
\text { MKR GSM } \\
\mathbf{1 4 0 0}\end{array}$ & Nilai Bias & $\begin{array}{c}\text { Nilai } \\
\text { Sensitifitas }\end{array}$ & Kesimpulan \\
\hline 3.3 Volt & 1024 & 1.65 & 0.33 & \\
& & & & $\begin{array}{l}\{\text { (Pembacaan } \\
\text { nilai analog } \\
\text { sensor x 3.3) / } \\
\end{array}$ \\
& & & & $1024(1.65)\} /$ \\
& & & 0.33 \\
\hline
\end{tabular}


Tabel Pengujian Guncangan Di Dalam Prototype

\begin{tabular}{|c|c|c|c|c|c|c|c|c|}
\hline $\begin{array}{c}\text { Berat } \\
\text { Peti } \\
\text { Telur }\end{array}$ & \multicolumn{2}{|c|}{$\begin{array}{l}\text { Berat } \\
\text { Telur }\end{array}$} & $\begin{array}{c}\text { Jara } \\
\mathbf{k} \\
\text { Tum } \\
\text { puk } \\
\text { an }\end{array}$ & $\begin{array}{l}\text { Pa } \\
\text { nja } \\
\text { ng }\end{array}$ & $\begin{array}{l}\text { Leb } \\
\text { ar }\end{array}$ & Z-axis & \multirow{2}{*}{$\begin{array}{c}\text { Waktu } \\
\text { 1/13/2020 11:27 }\end{array}$} & \multirow{2}{*}{$\begin{array}{c}\text { Kesimpulan } \\
\text { Telur Tidak } \\
\text { Pecah }\end{array}$} \\
\hline \multirow{10}{*}{$372 \mathrm{~g}$} & \multirow{10}{*}{$\begin{array}{c}323 \\
\mathrm{~g}\end{array}$} & \multirow{10}{*}{$\begin{array}{c}330 \\
\mathrm{~g}\end{array}$} & \multirow{10}{*}{$7 \mathrm{~cm}$} & \multirow{10}{*}{$\begin{array}{l}19 \\
\mathrm{~cm}\end{array}$} & \multirow{10}{*}{$\begin{array}{l}17 \\
\mathrm{~cm}\end{array}$} & $1.17 \mathrm{~Hz}$ & & \\
\hline & & & & & & $1.11 \mathrm{~Hz}$ & 1/13/2020 11:27 & $\begin{array}{l}\text { Telur Tidak } \\
\text { Pecah }\end{array}$ \\
\hline & & & & & & $1.14 \mathrm{~Hz}$ & 1/13/2020 11:27 & $\begin{array}{l}\text { Telur Tidak } \\
\text { Pecah }\end{array}$ \\
\hline & & & & & & $1.13 \mathrm{~Hz}$ & 1/13/2020 11:27 & $\begin{array}{l}\text { Telur Tidak } \\
\text { Pecah }\end{array}$ \\
\hline & & & & & & $1.11 \mathrm{~Hz}$ & 1/13/2020 11:27 & $\begin{array}{l}\text { Telur Tidak } \\
\text { Pecah }\end{array}$ \\
\hline & & & & & & $1.13 \mathrm{~Hz}$ & 1/13/2020 11:27 & $\begin{array}{l}\text { Telur Tidak } \\
\text { Pecah }\end{array}$ \\
\hline & & & & & & $1.07 \mathrm{~Hz}$ & 1/13/2020 11:27 & $\begin{array}{l}\text { Telur Tidak } \\
\text { Pecah }\end{array}$ \\
\hline & & & & & & $1.15 \mathrm{~Hz}$ & 1/13/2020 11:28 & $\begin{array}{l}\text { Telur Tidak } \\
\text { Pecah }\end{array}$ \\
\hline & & & & & & $0.79 \mathrm{~Hz}$ & 1/13/2020 11:28 & Telur Pecah \\
\hline & & & & & & $-0.05 \mathrm{~Hz}$ & 1/13/2020 11:28 & Telur Pecah \\
\hline
\end{tabular}

Keterangan :

Untuk keadaan normal guncangan memiliki rata-rata $1.12 \mathrm{~Hz}$ dan untuk guncangan yang berakibat pecah memiliki rata-rata $0.37 \mathrm{~Hz}$

\section{KESIMPULAN}

Setelah melakukan penelitian dan memecahkan masalah maka dapat di simpulkan yaitu sebagai berikut:

1. Untuk mengetahui posisi pengiriman dengan menggunkan Modul Gps Neo 6-m yang dapat mebaca nilai latitude dan longitude, data tersebut akan di kirim kedalam suatu web yang akan ditampilkan dalam bentuk maps.

2. Untuk mengetahui guncangan dengan menggunkan sensor Adx1335 dapat membaca pergerakan mobil dengan memberikan nilai z-axis, y-axis, z-axis untuk mengetahui guncangan yang dapat memecahkan telur, data tersebut dikirim ke dalam suatu web. 
3. Untuk mengetahui suhu pengiriman dengan menggunkan sensor DHT21 yang dapat membaca suhu, kelembapan didalam box, data tersebut untuk mengertahui tingkat pencemaran bakteri, kemudian data tersebut di kirim kedalam suatu web.

4. Dengan menggunakan Arduino MKR GSM 1400 yang dapat terkoneksi dengan internet melalui media sim card, dan menghubungkan Modul Gps Neo-6m, Sensor Adxl335, DHT21 terbentuklah suatu prototype yang dapat memonitoring posisi pengirim, getaran, keadaan suhu ketika proses pengiriman telur, kemudian data tersebut dapat dikirim kedalam suatu web secara mobile.

5. Telur tidak pecah diantara $1.11 \mathrm{~Hz}-1.17 \mathrm{~Hz}$ dengan rata-rata $1.12 \mathrm{~Hz}$ dan telur pecah diantara $-0.05 \mathrm{~Hz}-0.79 \mathrm{~Hz}$ dengan rata-rata rata-rata $0.37 \mathrm{~Hz}$.

\section{SARAN}

Dari hasil penelitian dan analisa yang dilakukan terdapat beberapa saran yang dapat diberikan dalam rangka pengembangan ke tahap berikutnya:

1. Pendeteksian suhu dapat di lakukan di setiap peti sehingga mendapatkan nilai temperature yang cukup presisi.

2. Pendeteksian guncangan dapat di lakukan di setiap peti sehingga mendapatkan nilai $\mathrm{z}$-axis yang cukup presisi.

3. Konsumen mendapatkan notifikasi secara otomatis ketika pesanan telah sampai, driver tidak perlu menekan (tactile switch) untuk memberikan status pengiriman.

4. Untuk id driver menggunakan RFID ketika mengendarai mobil pengiriman sehingga profil driver pengirman barang dapat diketahui.

5. Riwayat posisi pengiriman dapat terlihat dengan tarmpilan jalur yang sudah dilewati.

\section{DAFTAR PUSTAKA}

1. Pangestu, A., Sumardi, S. and Sudjadi, S., 2014. Perancangan alat pengaman dan tracking kendaraan sepeda motor dengan menggunakan mikrokontroler ATmega644PA. TRANSIENT, 3(4), pp.433-441.

2. Santoso, H. and Suryapradana, I., 2018. Sensor Monitoring Suhu Komputer Berbasis Port Paralel Dengan Menggunakan Rangkaian IC LM35 dan ADC 0804. Reaktom: Rekayasa Keteknikan dan Optimasi, 3(2).

3. Sembiring, Z. and Muliono, R., 2019. Perancangan Alat Pelacak Lokasi Dalam Mengantisipasi Penculikan Anak. Techno. Com, 18(1), pp.13-25.

4. Sulthoni, A. and Suprianto, B., 2018. Rancang Bangun Sistem Pendeteksi Vibrasi Pada Motor Sebagai Indikator Pengaman Terhadap Perubahan Beban Menggunakan Sensor Accelerometer GY-521 MPU 6050 Berbasis Arduino Uno. Jurnal Teknik Elektro, 7(03).

5. Zarkasi, M.I., Endri, J. and Sarjana, S., 2019. Rancang Bangun Pengatur Suhu Dan Kelembaban Ruang Server Berbasis IoT. J-SAKTI (Jurnal Sains Komputer dan Informatika), 3(2), pp.178-182. 